\title{
Spectrophotometric Determination of Vanadium(V) in Minerals, Steels, Soil and Biological Samples Using Phenothiazine Derivatives
}

\author{
Mahaveer B. Melwanki, Jaldappa Seetharamappa, ${ }^{\dagger}$ and Saraswati P. Masti \\ Department of Chemistry, Karnatak University, Dharwad-580 003, India
}

\begin{abstract}
Two simple, rapid and sensitive spectrophotometric methods have been proposed for the determination of vanadium(V) using butaperazine dimaleate (BPD) and propionyl promazine phosphate (PPP). These methods are based on the formation of red-colored radical cations on reaction with vanadium $(\mathrm{V})$ in phosphoric acid medium, with their absorbance maxima at $513 \mathrm{~nm}$. Beer's law is valid over the concentration range of $0.25-5.0 \mu \mathrm{g} \mathrm{ml}^{-1}$ and $0.2-4.0 \mu \mathrm{g} \mathrm{ml} l^{-1}$, with Sandell's sensitivity values of $6.1 \mathrm{ng} \mathrm{cm}^{-2}$ and $6.0 \mathrm{ng} \mathrm{cm}^{-2}$ for BPD and PPP respectively. The proposed methods have been successfully applied to the analysis of vanadium steels, minerals, biological samples and soil samples.
\end{abstract}

(Received March 29, 2001; Accepted June 11, 2001)

\begin{abstract}
Vanadium poisoning is an industrial hazard. ${ }^{1}$ Environmental scientists have declared vanadium as a potentially dangerous chemical pollutant that can play havoc with the productivity of plants, crops and the entire agricultural system. High amounts of vanadium are said to be present in fossil fuels, such as crude petroleum, fuels, oils, some coals and lignite. Burning of these fuels releases vanadium into the air, that then settles on the soil. There are cases of vanadium poisoning, the symptoms of which are nervous depression, coughing, vomiting, diarrhoea, anaemia and increased risk of lung cancer; such afflictions are sometimes fatal. ${ }^{2}$ Vanadium has also been reported as the index element in urban environmental pollution, especially air pollution. $^{3} \quad$ Vanadium in environmental samples has been determined by NAA, ${ }^{4}$ ICP-AES ${ }^{5}$ and AAS. $^{6}$ The first two methods are disadvantageous in terms of cost and instruments used in routine analysis. AAS is often lacking in sensitivity and is affected by matrix conditions of samples such as salinity. A number of catalytic methods having high sensitivity were reported. ${ }^{7-10}$ Catalytic solvent extraction methods are highly sensitive but are generally lacking in simplicity. Hence, accurate determination of vanadium at trace levels using simple and rapid methods is of paramount importance. Several spectrophotometric methods for the determination of vanadium $(\mathrm{V})$ have been reported, using various reagents such as anthranillic acid in the presence of $o$-phenanthroline, ${ }^{11} 3$ hydroxy-2-(4-methoxyphenyl)-6-methyl-4H-chromen-4-one, ${ }^{12}$ diethyldithiocarbamate, ${ }^{13} \quad N$-phenylcinnamohydroxamic acid and azide, $^{14} \quad$ cinnamohydroxamic acid, ${ }^{15} \mathrm{~N}$ phenylcinnamohydroxamic acid, ${ }^{16} \quad p$-sulfobenzeneazo-4-(2,3dihydroxopyridine), ${ }^{17}$ diphenylcarbazide in the presence of pyridine, ${ }^{18}$ 5-chloro-8-hydroxy-7-iodoquinoline, ${ }^{19}$ 2'-hydroxy acetophenone benzoyl hydrazone, ${ }^{20} \quad N$-p-bromophenyl thiobenzohydroxamic acid ${ }^{21}$ and Pyrogallol..$^{22}$ But most of these methods suffer from a number of limitations such as interferences by large number of ions; ${ }^{11-13}$ requiring
\end{abstract}

† To whom correspondence should be addressed.

E-mail: jseetharam@yahoo.com; j_seetharam@rediffmail.com extraction, ${ }^{14-16}$ heating and standing for a long time for color development ${ }^{17}$ followed by extraction; ${ }^{18}$ reduction to lower oxidation state followed by color development and extraction ${ }^{19}$ or reduction and heating for color development followed by extraction; ${ }^{20}$ or lack of sensitivity. ${ }^{11,13,20,22}$ A literature survey revealed that butaperazine dimaleate (BPD) and propionyl promazine phosphate (PPP) have not been used for the spectrophotometric determination of vanadium $(V)$ so far. In the present investigation we report two simple, rapid and sensitive spectrophotometric methods for the determination of vanadium $(\mathrm{V})$ using $\mathrm{BPD}$ and PPP. The methods have been successfully applied for the analysis of real samples.

\section{Experimental}

\section{Apparatus}

A Hitachi (Model U-2001) UV-visible spectrophotometer with $1 \mathrm{~cm}$ matched quartz cells was used for the absorbance measurements.

\section{Reagents and samples}

All chemicals were of analytical or pharmaceutical grade and quartz-processed high-purity water was used throughout.

A stock solution of vanadium $(\mathrm{V})$ was prepared using ammonium metavanadate (AR) in $100 \mathrm{ml}$ distilled water and were standardized using iron(II) solution. It was diluted to give a standard solution of $50 \mu \mathrm{g} \mathrm{ml}^{-1}$ vanadium(V). Each $0.2 \%$ solution of BPD and PPP was prepared separately. The aqueous solution of BPD is stable for 8 months and that of PPP is stable for 6 months, if stored in a refrigerator and protected from light. A $10 \mathrm{M} \mathrm{H}_{3} \mathrm{PO}_{4}$ was used throughout the study. Solutions of diverse ions of suitable concentrations were also prepared.

\section{Determination of vanadium $(V)$}

To a known volume of metal ion solution were added $7.5 \mathrm{ml}$ or $5 \mathrm{ml}$ of $\mathrm{H}_{3} \mathrm{PO}_{4}$ for BPD or PPP and $1 \mathrm{ml}$ of BPD or $2 \mathrm{ml}$ of PPP. The volume was made up to $25 \mathrm{ml}$ with distilled water. 


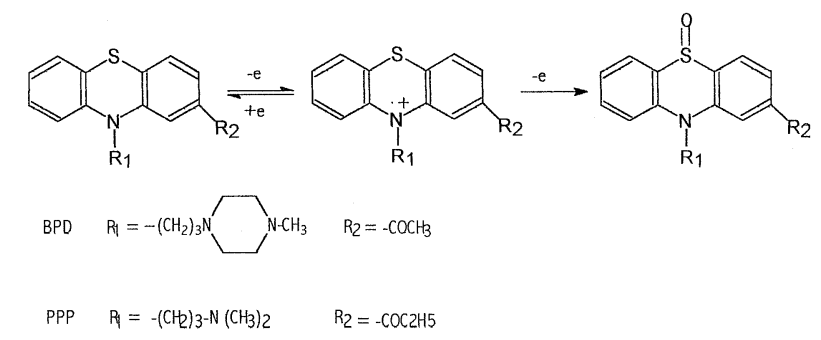

Fig. 1 Reaction scheme.

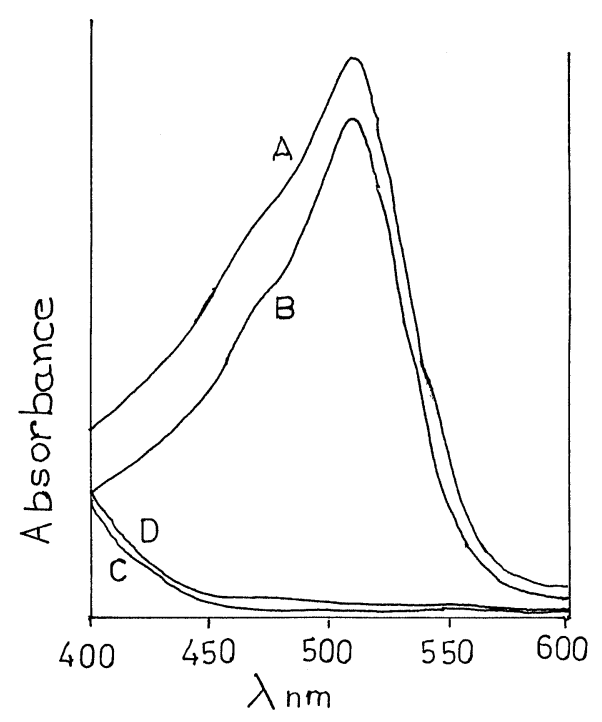

Fig. 2 Absorption spectra of A) V(V)-BPD, B) V(V)-PPP and reagent blanks of C) BPD and D) PPP.

The solution was mixed well and the absorbances were measured at $513 \mathrm{~nm}$. The amount of vanadium(V) in the sample solution was deduced from the calibration curve.

\section{Analysis of vanadium steel and ilmenite mineral}

An accurately weighed amount of vanadium steel or ilmenite mineral $(0.5 \mathrm{~g})$ was brought into solution as reported earlier. ${ }^{23}$ Suitable aliquots were taken and analyzed for vanadium(V) in both samples.

\section{Determination of vanadium in urine sample}

A known amount of vanadium(V) was added to a urine sample $(30 \mathrm{ml})$, taken in a $100 \mathrm{ml}$ micro-Kjeldahl flask. A 5-ml portion of concentrated $\mathrm{HNO}_{3}$ was added and the flask was placed on a digester under gentle heating. When the initial brisk reaction was over, the solution was removed and cooled. A 1$\mathrm{ml}$ drop of concentrated $\mathrm{H}_{2} \mathrm{SO}_{4}$ was added carefully, followed by the addition of $70 \%$ perchloric acid; heating was continued to dense white fumes. Heating was continued for at least 30 min and then the sample was cooled. The contents of the flask were filtered and diluted up to the mark with distilled water in a $100 \mathrm{ml}$ calibrated flask. A suitable aliquot of urine sample was taken and analyzed using the procedure outlined earlier.

\section{Determination of vanadium in soil samples}

Soil samples spiked with vanadium(V), obtained from Soil and Agricultural Chemistry, University of Agricultural Sciences, Dharwad, were brought into solution following the standard method. ${ }^{24}$ An aliquot of the solution was taken,
Table 1 Tolerance limits of diverse ions in the determination of vanadium $(\mathrm{V})$

\begin{tabular}{|c|c|c|c|c|c|}
\hline \multirow{2}{*}{$\begin{array}{l}\text { Ion or } \\
\text { species } \\
\text { added }\end{array}$} & \multicolumn{2}{|c|}{ Tolerance limit $/ \mu \mathrm{g} \mathrm{ml}^{-1}$} & \multirow{2}{*}{$\begin{array}{l}\text { Ion or } \\
\text { species } \\
\text { added }\end{array}$} & \multicolumn{2}{|c|}{ Tolerance limit $/ \mu \mathrm{g} \mathrm{ml}^{-1}$} \\
\hline & BPD & PPP & & BPD & PPP \\
\hline $\mathrm{Ni}(\mathrm{II})$ & 700 & 1000 & $\mathrm{Fe}(\mathrm{III})$ & 700 & 700 \\
\hline $\mathrm{Cu}(\mathrm{II})$ & 300 & 400 & $\mathrm{Al}(\mathrm{III})$ & 1000 & 1200 \\
\hline $\mathrm{Co}(\mathrm{II})$ & 400 & 500 & $\operatorname{Th}(\mathrm{IV})$ & 1800 & 2000 \\
\hline $\mathrm{Mn}(\mathrm{II})$ & 3500 & 2500 & $\mathrm{~W}(\mathrm{VI})$ & 40 & 60 \\
\hline $\mathrm{Cr}(\mathrm{III})$ & 1000 & 1200 & Fluoride & 2500 & 2200 \\
\hline $\mathrm{Na}(\mathrm{I})$ & 5000 & 5000 & Chloride & 6000 & 6000 \\
\hline $\mathrm{K}(\mathrm{I})$ & 5000 & 5000 & Sufate & 4000 & 4000 \\
\hline $\mathrm{Ca}(\mathrm{II})$ & 4500 & 4000 & Oxalate & 1500 & 1700 \\
\hline $\operatorname{Mg}(\mathrm{II})$ & 4500 & 4000 & Nitrate & 3000 & 3000 \\
\hline $\mathrm{Hg}(\mathrm{II})$ & 4500 & 4000 & Oxalate & 2000 & 1800 \\
\hline $\mathrm{Pb}(\mathrm{II})$ & 1200 & 1000 & Citrate & 5000 & 6000 \\
\hline $\mathrm{Mo}(\mathrm{VI})$ & 2200 & 2500 & Acetate & 7000 & 6500 \\
\hline $\mathrm{Zn}(\mathrm{II})$ & 5000 & 4000 & Tartarate & 500 & 550 \\
\hline $\mathrm{Cr}(\mathrm{VI})$ & 0.5 & 0.5 & Bromide & 1200 & 1500 \\
\hline $\mathrm{Ce}(\mathrm{IV})$ & 0.8 & 0.8 & EDTA & 500 & 500 \\
\hline
\end{tabular}

acidified with $10 \mathrm{M} \mathrm{H} \mathrm{H}_{3} \mathrm{PO}_{4}$, and analyzed following the procedure as described above.

\section{Results and Discussion}

Vanadium(V) instantaneously oxidizes BPD or PPP at room temperature in sulfuric, hydrochloric, phosphoric or acetic acid medium to give a red colored species that is believed to be a radical cation, ${ }^{25}$ which is irreversibly oxidized to a colorless sulfoxide with the loss of one more electron, as shown in Fig. 1. The formation of radical cations was also confirmed by passing an aliquot of the solution through cation and anion exchange resins. Only the cation exchange resin retained the red colored species, indicating the cationic nature of the red colored species. The red colored radical cations absorb at $513 \mathrm{~nm}$, where the reagent blanks do not absorb appreciably, as shown in Fig. 2. The stability and sensitivity of the red radical cations depend on the nature and the concentration of the acid medium used. These species are unstable in hydrochloric acid and in sulfuric acid and do not give maximum color intensity in acetic acid medium. They attained maximum color instantaneously in $2-4$ $\mathrm{M}$ and $1-3 \mathrm{M} \mathrm{H}_{3} \mathrm{PO}_{4}$ medium for BPD and PPP, respectively. Hence, phosphoric acid was selected for the study because of the higher sensitivity and longer stability of the colored species. A 6- and 8-fold molar excess of BPD and PPP are necessary for maximum color development. Below this concentration of BPD or PPP, less intense and unstable colored species were observed. It was also observed that the excess of the reagent had no effect either on the stability, sensitivity or on $\lambda_{\max }$. However, a 8- and 9.5-fold molar excess of BPD and PPP were used for the study. It was also observed that there was no appreciable change in the absorbance if the order of addition of reagents was varied. The absorbance values remained constant for $40 \mathrm{~min}$ in the temperature range of $15-50^{\circ} \mathrm{C}$.

\section{Analytical features}

The red colored species obeyed Beer's law in the concentration range of $0.25-5.0$ and $0.2-4.0 \mu \mathrm{g} \mathrm{ml} \mathrm{m}^{-1}$ of $\mathrm{V}(\mathrm{V})$ with molar absorptivity values of $1.05 \times 10^{5}$ and $7.18 \times 10^{4}$ $1 \mathrm{~mol}^{-1} \mathrm{~cm}^{-1}$ for BPD and PPP, respectively. Sandell's sensitivity values as calculated from Beer's law data were found 
Table 2 Determination of vanadium $(\mathrm{V})$ in vanadium steels and ilmenite

\begin{tabular}{|c|c|c|c|c|c|c|}
\hline \multirow{2}{*}{ Sample } & \multirow{2}{*}{ Composition, $\%$} & \multirow{2}{*}{$\begin{array}{l}\text { Cert. } \\
\text { value }\end{array}$} & \multicolumn{2}{|c|}{$\mathrm{V}(\mathrm{V})$ found $\mathrm{b}^{\mathrm{b}} / \mu \mathrm{g} \mathrm{ml}^{-1}$} & \multicolumn{2}{|c|}{$\mathrm{RSD}, \%$} \\
\hline & & & BPD & PPP & BPD & PPP \\
\hline \multirow[t]{3}{*}{ S-1 } & C, $0.18 ; \mathrm{Si}, 0.34 ; \mathrm{Mn}, 0.33 ; \mathrm{Ni}, 0.12 ; \mathrm{Cr}, 1.08$ & 1.44 & 1.42 & 1.45 & 1.06 & 1.07 \\
\hline & $\mathrm{Mo}, 0.85 ; \mathrm{V}, 0.87 ; \mathrm{Cu}, 0.22 ; \mathrm{P}, 0.018$ & 2.95 & 2.93 & 2.95 & 1.11 & 0.97 \\
\hline & $\mathrm{S}, 0.012 ; \mathrm{Ti}, 0.11 ; \mathrm{Al}, 0.042 ; \mathrm{B}, 0.0009$ & 3.63 & 3.35 & 3.33 & 0.97 & 0.87 \\
\hline \multirow[t]{3}{*}{$\mathrm{S}-2$} & $\mathrm{C}, 0.56 ; \mathrm{Si}, 0.24 ; \mathrm{Mn}, 0.91 ; \mathrm{Ni}, 0.23 ; \mathrm{Cr}, 1.03$ & 1.81 & 1.83 & 1.79 & 1.01 & 0.87 \\
\hline & $\mathrm{Mo}, 0.04 ; \mathrm{V}, 0.12 ; \mathrm{Cu}, 0.19 ; \mathrm{P}, 0.002 ; \mathrm{S}$ & 2.57 & 2.54 & 2.58 & 0.94 & 1.01 \\
\hline & 0.018 & 3.40 & 3.37 & 3.39 & 0.58 & 1.03 \\
\hline \multirow[t]{3}{*}{$\mathrm{I}-1^{\mathrm{a}}$} & $\mathrm{TiO}_{2}, 60.6 ; \mathrm{Fe}_{2} \mathrm{O}_{3}, 24.18 ; \mathrm{FeO}, 9.25 ; \mathrm{Al}_{2} \mathrm{O}_{3}$ & 1.54 & 1.52 & 1.57 & 0.54 & 1.04 \\
\hline & $0.96 ; \mathrm{MnO}, 0.39 ; \mathrm{Cr}_{2} \mathrm{O}_{3}, 0.12 ; \mathrm{MgO}, 0.89$ & 2.47 & 2.44 & 2.45 & 0.89 & $0.86]$ \\
\hline & $\begin{array}{l}\mathrm{P}_{2} \mathrm{O}_{5}, 0.21 ; \mathrm{ZrO}_{2}, 0.90 ; \mathrm{SiO}_{2}, 0.41 \text {, rare earths, } \\
\text { traces, 2.0; } \mathrm{V}_{2} \mathrm{O}_{5}, 0.15\end{array}$ & 3.64 & 3.61 & 3.63 & 0.78 & 1.02 \\
\hline \multirow[t]{3}{*}{$\mathrm{I}-2^{\mathrm{a}}$} & $\mathrm{TiO}_{2}, 54.2 ; \mathrm{Fe}_{2} \mathrm{O}_{3}, 14.2 ; \mathrm{FeO}, 26.6 ; \mathrm{Al}_{2} \mathrm{O}_{3}$ & 2.05 & 2.03 & 2.02 & 1.05 & 1.05 \\
\hline & 1.25; $\mathrm{MnO}, 0.4 ; \mathrm{Cr}_{2} \mathrm{O}_{3}, 0.07 ; \mathrm{MgO}, 1.03 ; \mathrm{P}_{2} \mathrm{O}_{5}$ & 2.55 & 2.59 & 1.04 & 0.93 & 2.59 \\
\hline & $\begin{array}{l}0.12 ; \mathrm{ZrO}_{2}, 0.80 ; \mathrm{SiO}_{2}, 0.68, \text { rare earths, } 0.12 \\
\text { traces, } 0.34 ; \mathrm{V}_{2} \mathrm{O}_{5}, 0.16\end{array}$ & 3.60 & 3.64 & 3.63 & 0.96 & 0.79 \\
\hline
\end{tabular}

a. Ilmenite samples. b. Average of five determinations.

Table 3 Determination of vanadium in urine and soil samples

\begin{tabular}{|c|c|c|c|c|c|c|c|c|c|}
\hline \multirow{2}{*}{ Sample } & \multicolumn{2}{|c|}{$\begin{array}{l}\text { Proposed method/ } \\
\qquad \mu \mathrm{g} \mathrm{ml}^{-1}\end{array}$} & \multicolumn{2}{|c|}{$\mathrm{RSD}, \%$} & \multirow{2}{*}{$\begin{array}{l}\text { Reported } \\
\text { method }^{\mathrm{a}} \\
\mu \mathrm{g} \mathrm{m} \mathrm{l}^{-1}\end{array}$} & \multicolumn{4}{|c|}{ Comparison with the standard method } \\
\hline & PPP & BPD & PPP & BPD & & $\mathrm{F}$ & $\mathrm{t}$ & $\mathrm{F}$ & $\mathrm{t}$ \\
\hline Urine 1 & 4.55 & 4.49 & 1.04 & 1.07 & 4.60 & 1.34 & 1.45 & 1.78 & 1.78 \\
\hline Urine 2 & 3.96 & 3.88 & 0.91 & 0.89 & 4.02 & 1.65 & 1.73 & 1.71 & 1.91 \\
\hline Soil 1 & 2.96 & 2.91 & 1.02 & 0.88 & 2.94 & 1.51 & 1.13 & 1.61 & 1.42 \\
\hline Soil 2 & 3.02 & 3.07 & 0.79 & 0.94 & 3.04 & 1.32 & 1.42 & 1.45 & 1.32 \\
\hline
\end{tabular}

a. Average of five determinations.

to be 6.1 and $6.0 \mathrm{ng} \mathrm{ml}^{-1}$ for $\mathrm{BPD}$ and PPP, respectively. Regression analyses of Beer's law plots at $513 \mathrm{~nm}$ revealed a good correlation $(r=0.9989$ and 0.9991). Graphs of the absorbance versus the concentration showed low intercept values $(0.047$ and 0.038$)$ and slope $(0.1269$ and 0.1315$)$ and are described by a regression equation, $Y=a+b X$ (where $Y$ is the absorbance of a $1 \mathrm{~cm}$ layer, $b$ is the slope, $a$ is the intercept and $X$ is the concentration of the drug in $\mu \mathrm{g} \mathrm{ml}^{-1}$ ), obtained by the least-squares method. The low relative standard deviation values $(0.93$ and 1.06$)$ and the range of error at $95 \%$ confidence level $(0.64$ and 0.81$)$ for the analyses of six replicates of $3 \mu \mathrm{g}$ $\mathrm{ml}^{-1}$ of $\mathrm{V}(\mathrm{V})$ indicated good precision and accuracy of the proposed methods.

\section{Effect of diverse ions}

In order to assess the analytical potential of the proposed methods, effects of some diverse ions which often accompany vanadium $(\mathrm{V})$ were examined by carrying out the determination of $3 \mu \mathrm{g} \mathrm{ml}^{-1}$ of vanadium(V) in the presence of a number of other ions. An ion was considered to interfere with the determination if the absorbance values obtained differed by more than $\pm 2 \%$ from that for vanadium(V) alone. The oxidizing agents such as $\mathrm{Cr}(\mathrm{VI})$ and $\mathrm{Ce}(\mathrm{IV})$ interfere seriously with the determination of $\mathrm{V}(\mathrm{V})$. The results are shown in Table 1.

\section{Analysis of steels and ilmenite mineral}

The results of the analysis of steels and ilmenite presented in Table 2 are in good agreement with the certified values. The low relative standard deviation values $(0.54-1.11)$ for analyses of five replicates indicated good precision of the proposed methods.

Analysis of vanadium in soil and urine samples and comparison with the reported method ${ }^{26}$

The vanadium $(V)$ was added to soil and urine samples which showed negative test for vanadium(V) and samples were analyzed as stated earlier. The recovery of vanadium $(\mathrm{V})$ was found to be satisfactory. The results of the analysis of urine and soil samples are given in Table 3 . The results were statistically compared by Students t-test and by the variance ratio F-test with those obtained by the reported method. ${ }^{26}$ The Students t-values at $95 \%$ confidence level did not exceed the theoretical values, indicating that there was no significant difference between the proposed and reported method. It was also noticed that the variance ratio $\mathrm{F}$-values calculated for $p=0.05$ did not exceed the theoretical values, indicating that there was no significant difference between the precision of the proposed methods and the reported method.

Thus the proposed methods can be used as alternative methods for the investigation of micro amounts of vanadium in minerals, steels, soil and biological samples, as the associated substances in these materials do not interfere with the determination of vanadium $(\mathrm{V})$. 


\section{Acknowledgements}

The authors thank Indian Rare Earths Ltd., Manavalkuruchi for supplying ilmnenite, M/s Mahindra Ugine Steel Co. Ltd., Khopoli and Visweswaraiah Iron and Steels Ltd., Bhadrawati for the supply of vanadium steels and to M/s Bayer A. G., Leverkusen and Byk Gulden Pharmazeutika, Konstanz, F. R. G. for the gift samples of butaperazine dimaleate and propionyl promazine phosphate respectively. Thanks are also due to the Head, Soil Science and Agricultural Chemistry, University of Agricultural Sciences, Dharwad for providing a variety of soil samples.

\section{References}

1. G. D. Clayton and F. E. Clayton (ed.), "Patty's Industrial Hygiene and Toxicology," 3rd ed., 1981, Vol. 2 A, Wiley, New York, 2013.

2. B. Venugopal and T. D. Luckey, "Metal Toxicity in Mammals," 1979, Vol. 2, Plenum Press, New York, 220.

3. S. Langard and T. Norseth, in "Handbook on the Toxicology of Metals", ed. L. Friberg, G. R. Norberg, and V. B. Vouk, 1986, Elsevier, Amsterdam.

4. R. R. Greenberg, and H. M. Kingston, Anal. Chem., 1983, 55,1160 .

5. C. F. Wang, T. T. Miau, J. Y. Perng, S. J. Yeh, P. C. Chiang, H. T. Tsai, and M. H. Yang, Analyst, 1989, 114, 1067.

6. T. Yamashige, M. Yamamoto, and H. Sunahara, Analyst, 1989, 114, 1071.

7. A. S. Mohamed and K. H. Fawy, Mikrochim. Acta, 2000, $134,229$.

8. W. Guangjian, W. Yongfang, and S. Xuxiang, Lihua
Jianyan, Huaxue Fence, 1997, 33, 126.

9. B. K. Balaji, G. Sarawanakumar, P. Murugesan, and G. Mishra, Talanta, 1998, 46, 1299.

10. A. A. Ensafi, M. K. Amini, and M. Mazloum, Anal. Lett., 1999, 32, 1927.

11. S. P. Arya and R. S. Chauhan, J. Indian Chem. Soc., 1995 , $72,69$.

12. N. Agnihotri, R. Das, and J. R. Mehta, J. Indian Chem. Soc., 2000, 77, 421.

13. S. P. Arya and K. Arora, J. Indian Chem. Soc., 1991, 68, 174.

14. A. Alemayehu and C. B. Singh, Chem. Anal. [Warsaw], 1998, 43,33

15. A. K. Chakrabarti, Talanta, 1995, 42, 1279.

16. C. B. Singh and T. Berhanu, Ann. Chim. [Rome], 1996, 86, 401.

17. Y. Sharma, Analyst, 1982, 107, 582.

18. S. P. Arya and J. L. Mulla, J. Indian Chem. Soc., 1987, 64, 238.

19. R. S. Chauhan and L. R. Kakkar, Chem. Anal. [Warsaw], 1997, 42, 729.

20. N. Agnihotri, R. Dass, and J. R. Mehta, J. Indian Chem. Soc., 1999, 76, 165.

21. A. Kumar, N. Mathur, P. Mathur, and S. P. Mathur, Rev. Roum. Chim., 1998, 43, 3.

22. N. Iranpoor, N. Maleki, S. Razi, and Safavia, Talanta, 1992, 39, 281.

23. M. B. Melwanki and J. Seetharamappa, Indian J. Chem., 2000, 39A, 465.

24. M. L. Jackson, "Soil Chemical Analysis," 1965, PrenticeHall, Englewood Cliffs, 326.

25. P. C. Dwivedi, K. Gurudath Rao, S. N. Bhat, and C. N. R. Rao, Spectrochim. Acta, 1975, 31, 129.

26. M. J. Ahmed and S. Banoo, Talanta, 1999, 48, 1085. 